\title{
Adolescent predictors of objectively measured physical activity and sedentary behaviour at age 42: the Amsterdam Growth and Health Longitudinal Study (AGAHLS)
}

Léonie Uijtdewilligen ${ }^{1}$, Amika S Singh ${ }^{1 *}$, Jos WR Twisk ${ }^{2,3}$, Lando LJ Koppes ${ }^{4,5}$, Willem van Mechelen ${ }^{1,5}$ and Mai JM Chinapaw ${ }^{1,5}$

\begin{abstract}
Background: This study investigated the associations of physical characteristics and personality in adolescence with physical activity and sedentary behaviour in adulthood.

Findings: Physical characteristics (i.e. objectively measured BMI, sum of skin folds, MOPER test battery performance), and personality (i.e. self-reported inadequacy, social inadequacy, rigidity, self-sufficiency/recalcitrance, dominance, achievement motivation, facilitating anxiety, debilitating anxiety, and social desirability) were assessed in 217 adolescent boys (Mean 13.0, SD 0.6) and girls (Mean 12.9, SD 0.6). Twenty-nine years later, at the age of 42, their physical activity and sedentary behaviour were assessed by means of accelerometry. Boys who scored lower on self-sufficiency/recalcitrance and higher on facilitating anxiety spent more time sedentary in adulthood. Girls with a superior standing high jump performance, and a lower score on social desirability spent more time sedentary in adulthood. In contrast with sedentary behaviour, physical activity at age 42 year could not be predicted by physical characteristics or personality in adolescence.

Conclusions: Sedentary behaviour in adulthood was partly explained by physical characteristics and/or personality in adolescence. Thus, our results suggest that it may be possible to identify people who are at risk of becoming sedentary at a rather young age.
\end{abstract}

Keywords: Accelerometry, Aerobic fitness, Longitudinal, Motor fitness, Personality

\section{Introduction}

Physical activity and sedentary behaviour are generally accepted as being two distinct classes of behaviour, which have been shown to be independently associated with energy expenditure, body weight, and metabolic factors [1-3].

Although a substantial body of literature has focused on drivers for adopting an inactive lifestyle the majority of these studies are cross-sectional [4]. The association between age, education, self-efficacy and physical activity

\footnotetext{
* Correspondence: a.singh@vumc.nl

'Department of Public and Occupational Health, EMGO+ Institute for Health and Care Research, VU University Medical Center, Amsterdam, The Netherlands

Full list of author information is available at the end of the article
}

has been frequently investigated, whereas other factors such as personality and fitness have been rarely examined [4]. Research on sedentary behaviour is rapidly growing [5,6], however, evidence on its determinants is relatively scarce.

Considering the above, research investigating under reported determinants of physical activity and sedentary behaviour in a prospective design and by means of objective measurement instruments is of great importance [4-6]. Therefore, the present study aims to extend existing knowledge by investigating which physical characteristics and personality in adolescence are longitudinally associated with objectively measured physical activity and sedentary behaviour in adulthood.

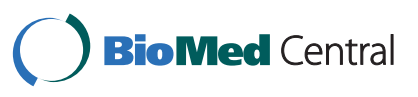




\section{Methods}

\subsection{Participants and procedures}

We used data collected at wave $1(1976 / 77)$ and wave 10 (2006) of the Amsterdam Growth and Health Longitudinal Study (AGAHLS). This longitudinal study started in $1976 / 1977$ monitoring growth, health, and lifestyle in more than 600 boys and girls aged 13 years. The study rationale, recruitment procedures and protocol have been reported in detail elsewhere [7]. We included participants with physical characteristics and/or personality data at wave 1 and data on physical activity and/or sedentary time at wave 10, resulting in a sample of 217 participants (33\% of the baseline sample; $42 \%$ male). Compared to those with complete data, participants without wave 10 data had a significant higher BMI, performed better in the arm pull test and scored higher on social desirability at baseline. The AGAHLS was approved by the medical ethics committee of the VU University Medical Center, Amsterdam, The Netherlands. All subjects gave their written informed consent [7].

\subsection{Measurements in adolescence}

\subsubsection{Physical characteristics}

Body height and weight were measured using a Harpenden digital readout, wall-mounted or portable stadiometer (Holtain, UK), and a spring balance (Van Vucht, the Netherlands), and BMI $\left(\mathrm{kg} / \mathrm{m}^{2}\right)$ was calculated. The sum of four skin folds (biceps, triceps, subscapular and supraliliac) was used as indicator of body fatness and measured with a Harpenden calliper (Holtain, UK) [8]

Aerobic fitness was assessed by measuring the maximal oxygen uptake $\left(\mathrm{VO}_{2} \max \right)$ while running on a treadmill (Quinton 18-45, USA). During the entire run, the expired air was analysed on $\mathrm{O}_{2}$ and $\mathrm{CO}_{2}$ by the Ergoanalyzer (Jaeger, the Netherlands), and subsequently expressed in $\mathrm{VO}_{2} \max \left(\mathrm{ml} \cdot \mathrm{min} \cdot \mathrm{kg}^{-2 / 3}\right)$ relative to the individuals' body weight [9].

Muscular fitness, i.e. the respondents' strength, speed, flexibility and endurance capacity was measured by means of the MOPER test battery including 8 different tests. The MOPER components are described in table 1 [10]. Validity and reliability of the MOPER tests have been shown to be acceptable in children $[11,12]$.

\subsubsection{Personality}

Personality traits were assessed using the youth versions of the Dutch Personality Inventory (DPI) [13], and the Achievement Motivation Test (AMT) [14]. The DPI assessed the participant's inadequacy, social inadequacy, rigidity, self-sufficiency/recalcitrance, and dominance. The AMT assessed the participants' achievement motivation, facilitating anxiety, debilitating anxiety, and social desirability. Psychometric properties of the DPI and AMT are presented in table 2.
Table 1 Description of the 8 MOPER elements

\begin{tabular}{|c|c|}
\hline MOPER test & Description \\
\hline \multicolumn{2}{|l|}{ Strength } \\
\hline 1. Arm pull & $\begin{array}{l}\text { The maximal force (in } \mathrm{kg} \text { ) pulled with the preferred } \\
\text { arm while standing }\end{array}$ \\
\hline $\begin{array}{l}\text { 2. Standing high } \\
\text { jump }\end{array}$ & The maximal standing vertical jump height (in $\mathrm{cm}$ ) \\
\hline $\begin{array}{l}\text { 3. Flexed arm } \\
\text { hang }\end{array}$ & $\begin{array}{l}\text { Maximal time (in sec) that eyes were kept above a } \\
\text { horizontal bar hanging in a bent arm position }\end{array}$ \\
\hline 4. 10 leg lifts & $\begin{array}{l}\text { Time (in sec) needed for lifting the legs } 10 \text { times } \\
\text { from horizontal to vertical position with stretched } \\
\text { knees while lying }\end{array}$ \\
\hline \multicolumn{2}{|l|}{ Speed } \\
\hline 5. Sprinting & $\begin{array}{l}\text { Time (in sec) needed to run } 10 \text { times between two } \\
\text { lines which were } 5 \text { meters apart }\end{array}$ \\
\hline 6. Plate tapping & $\begin{array}{l}\text { Time (in sec) needed to tap } 50 \text { times with 'best' } \\
\text { hand between two plates which were } 75 \text { centimetres } \\
\text { apart }\end{array}$ \\
\hline \multicolumn{2}{|l|}{ Flexibility } \\
\hline 7. Sit-and-reach & $\begin{array}{l}\text { Maximal reach (in } \mathrm{cm} \text { ) while sitting with extended } \\
\text { knees }\end{array}$ \\
\hline \multicolumn{2}{|l|}{ Endurance } \\
\hline $\begin{array}{l}\text { 8. Endurance } \\
\text { run }\end{array}$ & Maximal distance (in km) covered in 12 minutes \\
\hline
\end{tabular}

\subsection{Objectively measured physical activity levels and sedentary time in adulthood}

Physical activity was objectively measured using ActiGraph accelerometers (Model GT1M, ActiGraph, LLC, Fort Walton Beach, FL). At age 42, 345 participants were instructed to wear an accelerometer attached to a provided waist belt, for eight consecutive days during waking hours but not during water activities. The accelerometers were set to record acceleration and movement frequency at 60-second epochs. Data were considered eligible for analyses if the respondent had worn the accelerometer for at least one day for $\geq 500$ minutes per day. From the accelerometer data we computed two scores: physical activity (counts/min), and time spent sedentary (min/day) [15].

In total, 104 participants (30\%) did not provide ActiGraph data. Subjects with and without ActiGraph data were reasonably equal in terms of self-reported physical activity and sedentary behaviour. Of the remaining 241 participants, 12 (5\%) wore the accelerometer for < 500 minutes per day and were thus excluded from analyses. Those participants recorded significantly less counts per minute, less sedentary time and less wearing days.

\subsection{Statistical analyses}

We conducted all analyses for males and females separately. We used multiple regression analyses to investigate the associations of physical characteristics and personality in adolescence with physical activity (counts/ 
Table 2 Psychometric properties of the personality constructs based on figures of Luteijn et al. [13] and Hermans [14]

\begin{tabular}{|c|c|c|c|c|}
\hline Construct & \# items & Scoring & Reliability & Validity \\
\hline$\overline{D P P^{a}}$ & & & Chronbachs alpha ${ }^{b}$ & Correlations with school/parent report \\
\hline $\begin{array}{l}\text { Inadequacy } \\
\text { (e.g. having vague physical complaints) }\end{array}$ & 28 & $\begin{array}{l}\text { Example question: I do not } \\
\text { make friends easily }\end{array}$ & $.85 ; .87$ & $\begin{array}{l}-.20 \text { (cognitive functioning) } \\
-.25 \text { (concentration, ability to work } \\
\text { on and work independently) }\end{array}$ \\
\hline $\begin{array}{l}\text { Social inadequacy } \\
\text { (e.g. avoiding social contacts) }\end{array}$ & 13 & $\begin{array}{l}\text { Scale: true (scored 2), not } \\
\text { true (scored 0), ? (scored 1) } \\
\text { for all questions }\end{array}$ & $.75 ; .82$ & .26 (behavioural assessment) \\
\hline $\begin{array}{l}\text { Rigidity } \\
\text { (e.g. the need for regularity) }\end{array}$ & 25 & $\begin{array}{l}\text { Sum score: the higher the } \\
\text { more }\end{array}$ & $.76 ; .83$ & $\begin{array}{l}.26 \text { (cognitive functioning) } \\
.22 \text { (achievement motivation) }\end{array}$ \\
\hline $\begin{array}{l}\text { Self-sufficiency/recalcitrance } \\
\text { (e.g. mistrust of others) }\end{array}$ & 24 & & $.74 ; .75$ & $\begin{array}{l}-.23 \text { (cognitive functioning) } \\
-.27 \text { (social-motivational functioning) }\end{array}$ \\
\hline $\begin{array}{l}\text { Dominance } \\
\text { (e.g. trying to be the boss) }\end{array}$ & 15 & & $.59 ; .70$ & .19 (parental perception of child) \\
\hline$A M T^{c}$ & & & Test-retest correlations $^{d}$ & Correlations with grades ${ }^{e}$ \\
\hline $\begin{array}{l}\text { Achievement motivation } \\
\text { (e.g. the need to achieve) }\end{array}$ & 39 & $\begin{array}{l}\text { Example question: I feel } \\
\text { sometimes/seldom/never } \\
\text { bored }\end{array}$ & $.48 ; .74$ & $.18 ; .35$ \\
\hline $\begin{array}{l}\text { Facilitating anxiety } \\
\text { (fear of failure, leading to higher } \\
\text { achievements) }\end{array}$ & 17 & $\begin{array}{l}\text { Scale: all questions have } \\
\text { different answering options } \\
\text { on a three or four point scale }\end{array}$ & $.46 ; .68$ & $.05 ; .17$ \\
\hline $\begin{array}{l}\text { Debilitating anxiety } \\
\text { (fear of failure, leading to lower } \\
\text { achievements) }\end{array}$ & 15 & $\begin{array}{l}\text { Sum score: the higher the } \\
\text { more }\end{array}$ & $.47 ; .72$ & $-.17 ;-.25$ \\
\hline $\begin{array}{l}\text { Social desirability } \\
\text { (e.g. the tendency to give the most } \\
\text { socially acceptable answers) }\end{array}$ & 23 & & $.40 ; .81$ & $.01 ; .07$ \\
\hline
\end{tabular}

${ }^{\mathrm{a}} \mathrm{DPI}=$ Dutch Personality Inventory

${ }^{b}$ Numbers represent a range of Chronbachs alpha among different experimental groups (i.e. primary school pupils, secondary school pupils and 'general')

${ }^{c}$ AMT = Achievement Motivation Test

d Numbers represent a range of test-retest correlations among boys and girls in different age groups

e Numbers represent a range of correlations between the ATM constructs and grades during different periods of the curriculum (i.e. Christmas and grade transition)

min) and sedentary behaviour (min/day) in adulthood. We entered all physical characteristics in one block while correcting for skeletal maturation, and removed variables with the lowest $p$-value from the model until only variables with a $p$-value $<.05$ remained. The same was done for personality, though we did not correct for skeletal maturation in these analyses. For all analyses we used the Statistical Package of Social Sciences, 15.0 for Windows (SPSS inc., Chicago, Illinois, USA).

\section{Results}

Table 3 presents descriptive data of the participants during adolescence and adulthood.

Multivariate regression analyses revealed no significant associations between physical characteristics and/or personality in adolescence and physical activity in adulthood (data not shown). Regarding sedentariness, in males, a lower score on self-sufficient/recalcitrant and a higher score on facilitating anxiety was associated with more minutes spent sedentary in adulthood. In females, a superior standing high jump performance, and a lower score on social desirability were associated with more minutes spent sedentary at age 42 (Table 4).

\section{Discussion}

Previous studies suggest that people with an 'easy going' personality practice healthier lifestyles $[16,17]$. However, we found that male subjects who possessed more self-

Table 3 Descriptive data of the male and female participants in adolescence and adulthood

\begin{tabular}{|c|c|c|c|c|}
\hline & \multicolumn{2}{|c|}{$\begin{array}{l}\text { Males } \\
(\mathrm{N}=92)\end{array}$} & \multicolumn{2}{|c|}{$\begin{array}{l}\text { Females } \\
(\mathrm{N}=125)\end{array}$} \\
\hline & Mean & S.D. & Mean & S.D. \\
\hline \multicolumn{5}{|l|}{ Adolescence } \\
\hline Age (y) & 13.0 & 0.6 & 12.9 & 0.6 \\
\hline Height (cm) & 157.9 & 7.7 & 159.8 & 7.8 \\
\hline Weight (kg) & 41.8 & 6.4 & 45.4 & 7.5 \\
\hline $\mathrm{BMI}\left(\mathrm{kg} / \mathrm{m}^{2}\right)$ & 16.9 & 1.4 & 17.7 & 2.1 \\
\hline Sum of four skin folds (cm) & 2.7 & 0.9 & 3.6 & 1.3 \\
\hline \multicolumn{5}{|l|}{ Adulthood } \\
\hline Physical activity (counts/min) ${ }^{a}$ & 344.3 & 109.6 & 349.9 & 99.8 \\
\hline Sedentary time $(\mathrm{min} / \text { day })^{\mathrm{a}}$ & 517.7 & 89.5 & 457.8 & 70.4 \\
\hline Wear time accelerometer (days) & 7.9 & 2.1 & 8.0 & 1.7 \\
\hline
\end{tabular}

a To be included in the analyses, participants had to wear the ActiGraph for at least one day, for $\geq 500$ minutes 
Table 4 Prediction model of sedentary time ( $\mathrm{min} / \mathrm{day}$ ) at the age of $\mathbf{4 2}$ years for males and females

\begin{tabular}{|c|c|c|c|c|c|c|}
\hline Model & & Constant & $\beta$ & $\mathrm{Cl}$ & $\begin{array}{l}\mathrm{p}- \\
\text { value }\end{array}$ & $\mathrm{R}^{2 \mathrm{a}}$ \\
\hline \multicolumn{7}{|l|}{ Males } \\
\hline \multirow[t]{2}{*}{$1^{\mathrm{b}}$} & $\begin{array}{l}\text { Self-sufficiency/ } \\
\text { recalcitrance }\end{array}$ & 639.01 & -3.92 & $\begin{array}{l}-6.82 \\
-1.01\end{array}$ & .01 & 36.3 \\
\hline & Facilitating anxiety & & 5.13 & $\begin{array}{l}.08 \\
10.19\end{array}$ & $<.05$ & \\
\hline \multicolumn{7}{|l|}{ Females } \\
\hline $1^{\mathrm{b}}$ & Social desirability & 479.24 & -4.35 & $\begin{array}{l}-8.59 \\
-.12\end{array}$ & .04 & 4.3 \\
\hline $2^{c}$ & Standing high jump & 376.55 & 2.82 & $.26 ; 5.39$ & .03 & 3.9 \\
\hline
\end{tabular}

${ }^{a}$ Values of $R^{2}$ are multiplied by 100 , numbers represent percentages

${ }^{\mathrm{b}}$ Model 1 included all personality characteristics entered in one block

${ }^{c}$ Model 2 included all physical characteristics entered in one block

sufficiency/recalcitrance were less sedentary as adults. Individuals with a more self-sufficient/recalcitrant personality, characterised by higher levels of rebellion and hostility [13], might be more restless and volatile and thus engage in less sedentary behaviour.

Males who scored higher on facilitating anxiety, characterised by impulsivity and sensation/stimulation seeking, spent more time being sedentary in adulthood. Also, a superior standing high jump performance in girls was associated with more sedentary time in adulthood. Previous studies found that similar personality and physical characteristics were positively associated with physical activity; i.e. extravert and conscientious people were more physically active[18], and sufficient levels of muscular fitness were predictors of physical activity at a later age $[19,20]$. In our study these characteristics predicted sedentary time as well. This supports the assumption that physical activity and sedentary behaviour are two different types of behaviour [1-3], and that people who are sufficiently physically active can be highly sedentary at the same time. Since little evidence on determinants of sedentary behaviour is available, more prospective research needs to be conducted to confirm our findings and establish the mechanisms causing these relationships.

To the best of our knowledge, up to now the association between social desirability and sedentary time has only been explored by Jago and colleagues [21]. Although Jago and colleagues examined a slightly different study sample (10 to 14-year old Boy Scouts) with different measures (self-reported sedentary time instead of accelerometry) using a cross-sectional design, a comparable inverse association between social desirability and sedentariness was found. A possible explanation for this association might be that people with a less social desirable nature care less about prevailing norms in society and therefore participate less in social desirable behaviour. Currently much attention is paid to initiatives trying to increase people's physical activity level and decrease their time spent sedentary [22]. People who score low on social desirability may be less likely to participate in such initiatives.

\section{Limitations}

Several limitations are noteworthy. First, participants were rather active as compared to the general Dutch population [23], which may be explained by the participants' relatively high educational background [24]. Therefore, the current results may not be generalisable to the Dutch population. Second, our study sample significantly differed from the baseline sample and from subjects who did not provide ActiGraph data at age 42 which may have biased our results Third, accelerometry is not a gold standard for measuring physical activity nor sedentary time. Although accelerometry provides real time data storage, it does not provide qualitative information on the type of activity. Besides, accelerometry underestimates some activities, such as cycling. Since cycling is a common method of transportation in the Netherlands, underestimation of physical activity may have occurred. Therefore, our findings should be interpreted with caution.

\section{Conclusion}

Sedentary behaviour in adulthood was partly explained by physical characteristics and/or personality in adolescence. Our findings need to be confirmed in other studies.

\section{Author details}

'Department of Public and Occupational Health, EMGO+ Institute for Health and Care Research, VU University Medical Center, Amsterdam, The Netherlands. ${ }^{2}$ Department of Health Sciences, Section Methodology and Applied Biostatistics, VU University Medical Center, Amsterdam, The Netherlands. ${ }^{3}$ Department of Epidemiology and Biostatistics, VU University Medical Center, Amsterdam, The Netherlands. ${ }^{4}$ Division Work and Employment, TNO, Hoofddorp, The Netherlands. ${ }^{5}$ Body@Work, Research Center Physical Activity, Work and Health, TNO-VU University Medical Center, Amsterdam, The Netherlands.

\section{Authors' contributions}

LU performed the statistical analyses, interpreted the data and drafted the manuscript. AS participated in the design of the study, contributed to the analyses and interpretation of data and provided critical revision of the manuscript. JT participated in the fund raising, conception and design of the current study, provided statistical expertise and critical revision of the manuscript, and participated in the conception, design and data acquisition of AGAHLS. LK participated in the fund raising, conception and design of the study, and provided critical revision of the manuscript. WM provided critical revision of the manuscript, and participated in the conception, design, fund raising and data acquisition of AGAHLS. MC participated in the design of the study, contributed to the analyses and interpretation of data and provided critical revision of the manuscript. All authors read and approved the final manuscript.

\section{Competing interests}

The authors declare that they have no competing interests. 
Received: 16 December 2010 Accepted: 2 October 2011

Published: 2 October 2011

\section{References}

1. Tremblay MS, Colley RC, Saunders TJ, Healy GN, Owen N: Physiological and health implications of a sedentary lifestyle. Appl Physiol Nutr Metab 2010, 35:725-740.

2. Hamilton MT, Hamilton DG, Zderic TW: Role of low energy expenditure and sitting in obesity, metabolic syndrome, type 2 diabetes, and cardiovascular disease. Diabetes 2007, 56:2655-2667.

3. Healy GN, Wijndaele K, Dunstan DW, Shaw JE, Salmon J, Zimmet PZ, Owen N: Objectively measured sedentary time, physical activity, and metabolic risk: the Australian Diabetes, Obesity and Lifestyle Study (AusDiab). Diabetes Care 2008, 31:369-371.

4. Trost SG, Owen N, Bauman AE, Sallis JF, Brown W: Correlates of adults' participation in physical activity: review and update. Med Sci Sports Exerc 2002, 34:1996-2001.

5. Pate RR, O'Neill JR, Lobelo F: The evolving definition of "sedentary". Exerc Sport Sci Rev 2008, 36:173-178.

6. Biddle SJ: Sedentary behavior. Am J Prev Med 2007, 33:502-504.

7. Kemper HC, Snel J, van Mechelen W: General Introduction. In Amsterdam Growth and Health Longitudinal Study. A 23-Year Follow-Up from Teenager to Adult about Lifestyle and Health. Medicine and Sport Science. Volume 47. Edited by: Kemper HCG, Borms J, Hebbelinck M, Hills AP. Basel: Karger; 2004:5-20

8. van Lenthe FJ, Kemper HC, van Mechelen W, Twisk JW: Development and tracking of central patterns of subcutaneous fat in adolescence and adulthood: the Amsterdam Growth and Health Study. Int J Epidemiol 1996, 25:1162-1171.

9. Kemper HC, Twisk JW, Koppes LL, van Mechelen W, Post GB: A 15-year physical activity pattern is positively related to aerobic fitness in young males and females (13-27 years). Eur J Appl Physiol 2001, 84:395-402.

10. Runhaar J, Collard DC, Singh AS, Kemper HC, van Mechelen W, Cinapaw M: Motor fitness in Dutch youth: differences over a 26-year period (19802006). J Sci Med Sport 2010, 13:323-328.

11. Bovend'eerd JHF, Bernink MJE, Van Hijfte T, Ritmeester JW, Kemper HCG, Verschuur R: De MOPER fitness test [The MOPER fitness test] Haarlem: De Vrieseborch; 1980.

12. Leyten C: De MOPER fitheidstest, onderzoeksverslag $9 \mathrm{t} / \mathrm{m} 11$ jarigen [The MOPER fitness test, research paper 9 to 11 year olds] Haarlem: De Vrieseborch; 1982.

13. Luteijn F, Van Dijk H, Van der Ploeg FAE: Handleiding bij de NPV J, Herziene Uitgave [Manual of the Dutch Personality Inventory, Revised Edition] Lisse: Swets \& Zeitlinger; 1989.

14. Hermans HJM: Handleiding bij de PMT-K [Manual of the Achievement Motivation Test Youth Version] Lisse: Swets \& Zeitlinger; 1983.

15. Hagströmer M, Oja P, Sjöström M: Physical activity and inactivity in an adult population assessed by accelerometry. Med Sci Sports Exerc 2007, 39:1502-1508

16. de Bruijn GJ, Kremers SPJ, van Mechelen W, Brug J: Is personality related to fruit and vegetable intake and physical activity in adolescents? Health Educ Res 2005, 20:635-644.

17. Vingerhoets AJJM, Croon M, Jeninga AJ, Menges $\amalg$ : Personality and health habits. Psychol Health 1990, 4:333-342.

18. Rhodes RE, Smith NE: Personality correlates of physical activity: a review and meta-analysis. Br J Sports Med 2006, 40:958-965.

19. Dennison BA, Straus JH, Mellits ED, Charney E: Childhood physical fitness tests: predictor of adult physical activity levels? Pediatrics 1988, 82:324-330.

20. Tammelin T: A review of longitudinal studies on youth predictors of adulthood physical activity. Int J Adolesc Med Health 2005, 17:3-12.

21. Jago R, Baranowski T, Baranowski JC, Cullen KW, Thompson DI: Social desirability is associated with some physical activity, psychosocial variables and sedentary behavior but not self-reported physical activity among adolescent males. Health Educ Res 2007, 22:438-449.

22. Jepson RG, Harris FM, Platt $S$, Tannahill $C$ : The effectiveness of interventions to change six health behaviours: a review of reviews. $B M C$ Public Health 2010, 10:538-553.

23. TNO: Trendrapport Bewegen en Gezondheid 2008-2009 [Trend report on Physical activity and Health 2008-2009] Leiden; 2010.
24. He XZ, Baker DW: Differences in leisure-time, household, and workrelated physical activity by race, ethnicity, and education. J Gen Intern Med 2005, 20:259-266.

doi:10.1186/1479-5868-8-107

Cite this article as: Uijtdewilligen et al: Adolescent predictors of objectively measured physical activity and sedentary behaviour at age 42: the Amsterdam Growth and Health Longitudinal Study (AGAHLS). International Journal of Behavioral Nutrition and Physical Activity 2011 8:107.

\section{Submit your next manuscript to BioMed Central and take full advantage of:}

- Convenient online submission

- Thorough peer review

- No space constraints or color figure charges

- Immediate publication on acceptance

- Inclusion in PubMed, CAS, Scopus and Google Scholar

- Research which is freely available for redistribution

Submit your manuscript at www.biomedcentral.com/submit

Ciomed Central 